\title{
Passive acoustic monitoring reveals spatiotemporal segregation of two fish-eating killer whale Orcinus orca populations in proposed critical habitat
}

\author{
Candice K. Emmons ${ }^{1, *}$, M. Bradley Hanson ${ }^{1}$, Marc O. Lammers ${ }^{2}$ \\ ${ }^{1}$ Conservation Biology Division, Northwest Fisheries Science Center, National Marine Fisheries Service, \\ National Oceanic Atmospheric Administration, 2725 Montlake Boulevard East, Seattle, Washington 98112, USA \\ ${ }^{2}$ Hawaiian Islands Humpback Whale National Marine Sanctuary, 726 South Kihei Road, Kihei, Hawaii 96753, USA
}

\begin{abstract}
Competition for prey resources among ecologically similar populations that occur in sympatry can be reduced by spatiotemporal resource partitioning. Understanding patterns of habitat use of cetaceans can be difficult since they are highly mobile and can have large home ranges. We used passive acoustic monitoring at 15 sites along the coast of Washington State, USA, to assess habitat use patterns of 2 sympatric populations of fish-eating killer whales Orcinus orca: northern residents (NRKW) and southern residents (SRKW). This area is part of the ocean distributions of a number of important runs of Chinook salmon Oncorhyncus tshawytscha, the preferred prey of both populations, and is proposed critical habitat for SRKW. We compared monthly occurrence of both populations at recorder locations grouped by their proximity to the Strait of Juan de Fuca to the north and the Columbia River to the south in one analysis and by their distance from shore in a second analysis. NRKW and SRKW were detected throughout the year with spring and fall peaks in occurrence. The northernmost sites accounted for $93 \%$ of NRKW detections, while less than half of SRKW detections were at these sites. SRKW were most frequently detected at nearshore sites (83\% of detections), while the majority of NRKW detections were at mid-shelf and deep sites (94\% of detections). This study provides further information about the habitat use of these resident killer whale populations with implications for their management and conservation.
\end{abstract}

KEY WORDS: Killer whales · Critical habitat · Passive acoustic monitoring

\section{INTRODUCTION}

Sympatric species, or populations within a species, that have similar prey preferences may compete for resources. Overlap in range does not always result in direct interaction due to the potential for spatiotemporal resource partitioning through variation in the timing and location of foraging behavior (Ratcliffe et al. 2014, Oviedo et al. 2018, Genov et al. 2019). This may lead to differences in habitat use among populations, resulting in different exposure to human activities (Genov et al. 2019, Teixeira et al. 2021).

${ }^{*}$ Corresponding author: candice.emmons@noaa.gov
In odontocetes, dietary differentiation is one of the main ecological process that results in divergence in habitat use (Bearzi 2005), but social structure is also an important factor affecting long-term habitat use patterns in long-lived species such as killer whales Orcinus orca and sperm whales Physeter macrocephalus (Brent et al. 2015, Eguiguren et al. 2019). Understanding cetacean habitat use patterns is difficult due to their highly mobile nature and large home ranges. In many areas, visual monitoring is limited and cost prohibitive due to protracted periods of inclement weather, remote access, and short daylight hours. In these locations, remote acoustic monitoring

(C) Outside USA, the US Government 2021. Open Access under Creative Commons by Attribution Licence. Use, distribution and reproduction are unrestricted. Authors and original publication must be credited.

Publisher: Inter-Research · www.int-res.com 
is an effective alternative for vocally active species such as killer whales which produce discrete pulsed calls, whistles, and echolocations clicks (Schevill \& Watkins 1966, Hanson et al. 2013, Rice et al. 2017).

Three sympatric yet distinct killer whale ecotypes occur in the coastal waters of Washington State, USA, that differ in diet, ecology, behavior, and morphology (Ford et al. 2000, Emmons et al. 2019a). Bigg's killer whales forage on marine mammals, while offshore and resident killer whales are piscivorous (Ford et al. 1998, Dahlheim et al. 2008). Each ecotype can be identified acoustically by the groupspecific pulsed calls they produce (Yurk et al. 2010, Riera et al. 2019). Within the resident ecotype, specific calls distinguish smaller nested social units, including populations, acoustic clans, or pods (Ford 1987).

Two populations of fish-eating or 'resident' killer whales, Northern Residents (NRKW) and Southern Residents (SRKW), have been well studied in their summer range of the inland waters of British Columbia and Washington State. NRKW are comprised of 3 acoustic clans (A, G, and R clans) of approximately 300 individuals (Towers et al. 2020), while SRKW are a single acoustic clan ( $\mathrm{J}$ clan) of approximately 75 individuals (Center for Whale Research unpubl. data). NRKW and SRKW are both salmon specialists with a strong preference for Chinook salmon Oncorhyncus tshawytscha (Ford \& Ellis 2006). The 2 populations are partially sympatric, but socially distinct from each other (Ford et al. 1998, 2000).

Population decline, small population size, and the existence of several anthropogenic threats led to SRKW being listed as 'endangered' under both the US Endangered Species Act (ESA) and Canada's Species at Risk Act (SARA), while NRKW are listed as 'threatened' under SARA. Since these listings, NRKW have continued to grow at $2.9 \% \mathrm{yr}^{-1}$ while SRKW have failed to recover (Fisheries and Oceans Canada 2018, Towers et al. 2020).

Critical habitat was designated for SRKW in the inland waters of Washington State in 2006 (NMFS 2006), but the whales typically only spend a fraction of the year in these waters (Olson et al. 2018). Passive acoustic monitoring (PAM) has been used at selected sites along the west coasts of Washington, Oregon, and California to better understand SRKW movements outside of the inland waters, especially during winter months (Hanson et al. 2013, Rice et al. 2017), and has led in part to the proposed expansion of critical habitat to include these waters (NMFS 2019).

In 2014, PAM efforts were increased to 15 monitoring sites along the Washington coast to better under- stand year-round SRKW movements and potential anthropogenic threats (Emmons et al. 2019b). Resident killer whale movements have been hypothesized to be driven by the abundance of Chinook salmon (Olson et al. 2018), and the continental shelf off the Washington coast is a part of the ocean distribution of a number of important Chinook salmon runs (Weitkamp 2010, Shelton et al. 2019). This part of the coast is bordered by the Strait of Juan de Fuca to the north and the Columbia River to the south, and the associated Juan de Fuca eddy and Columbia River plume play an important role in oceanographic and biological processes (Hickey \& Banas 2003). The Strait of Juan de Fuca acts as a funnel for salmon returning to their natal rivers such as the Fraser River, the primary source of SRKW's preferred summer prey (Hanson et al. 2010). The Columbia River supports large runs of spring, summer, and fall Chinook salmon, and previous analyses have suggested that spring runs are seasonally important to SRKW (Zamon et al. 2007, Ayres et al. 2012, Hanson et al. 2013).

NRKW also occur along the Washington coast (Rice et al. 2017), but to what extent is uncertain. NRKW and SRKW are ecologically similar, especially in regard to their diet (Ward et al. 2013). Thus, it is important to understand the role that intraspecies competition may play in limiting the recovery of SRKW (Chasco et al. 2017). Here, we used a large network of passive acoustic recorders to assess the habitat use patterns of both NRKW and SRKW along the Washington coast. Specifically, we compared monthly occurrence of both populations at recorder locations grouped by their proximity to the Strait of Juan de Fuca to the north and the Columbia River to the south in one analysis and by their distance from shore in a second analysis. Based on previous studies (Yurk et al. 2010, Rice et al. 2017, Riera et al. 2019), we hypothesized that we would observe spatial and/or temporal habitat partitioning by SRKW and NRKW in order to minimize competitive interactions for Chinook salmon.

\section{MATERIALS AND METHODS}

\subsection{Field efforts}

PAM was conducted at 15 sites off the Washington coast using ecological acoustic recorders (EARs; Lammers et al. 2008). These sites spanned the width of the continental shelf from the Canadian border to the north and the Columbia River to the south 


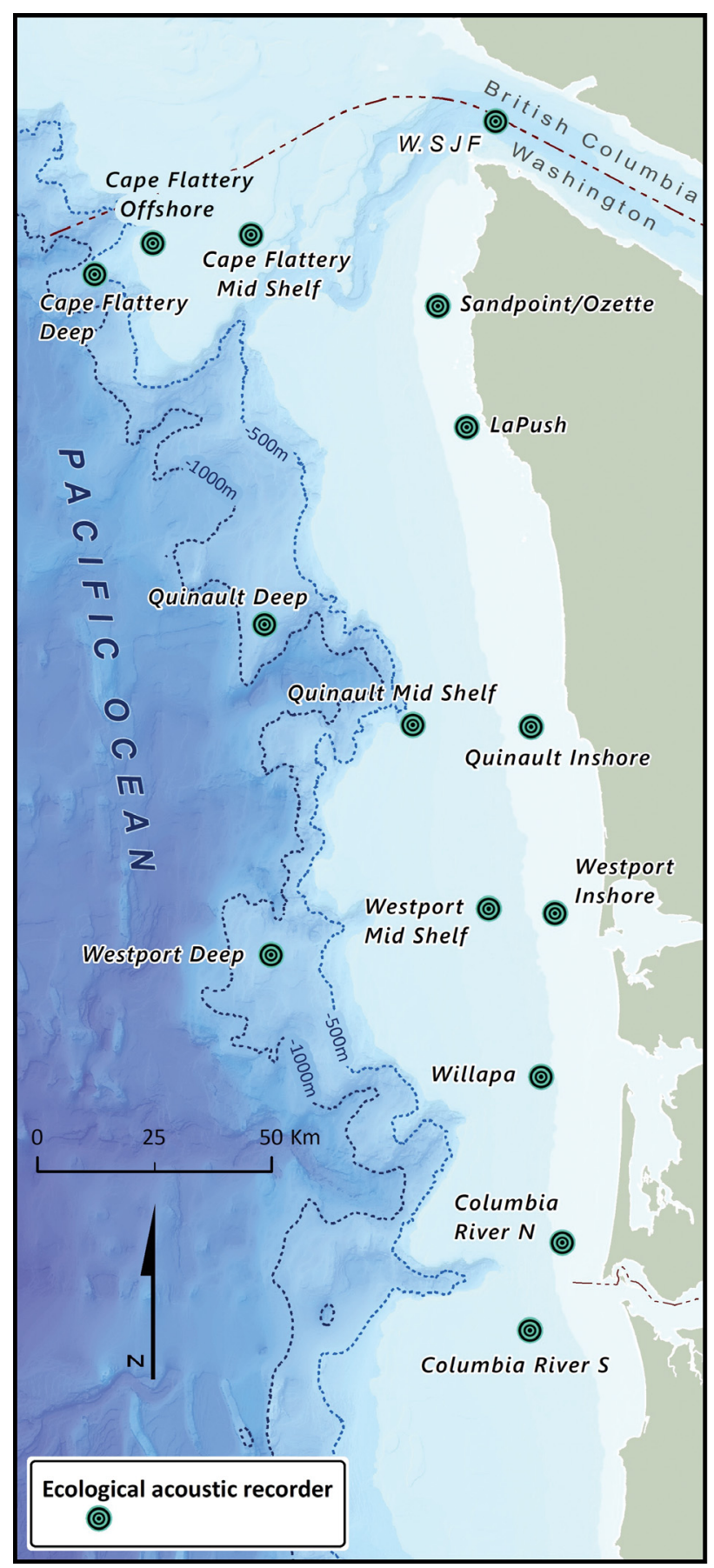

Fig. 1. Coast of Washington State, USA, and locations of acoustic recorders deployed from 2014-2017

(Fig. 1). Sites were selected based on previous sightings and satellite tag locations of SRKW, bathymetric features, accessibility for mooring deployment and recovery, and minimizing the likelihood of fishery interactions.

An EAR can be programmed either as an event recorder triggered by defined acoustic parameters or to record on a dedicated duty cycle. In this study, EARs were programmed to record on a $15 \%$ duty cycle, resulting in $90 \mathrm{~s}$ of continuous recording every $600 \mathrm{~s}$. The duty cycle was chosen based on several factors, including the likelihood of capturing groupspecific killer whale pulsed calls, expected power consumption, and drive space that would allow for data collection for up to $1 \mathrm{yr}$. The sampling rate used on all deployments was $25 \mathrm{kHz}$, which provided approximately $12.5 \mathrm{kHz}$ of bandwidth. This sampling rate was chosen as a trade-off for preserving disk drive space and battery life while still allowing for identification of killer whale pulsed calls. These calls typically range in frequency between 1 and $10 \mathrm{kHz}$, but some calls contain a high frequency component and contain harmonics up to $30 \mathrm{kHz}$ (Ford 1989, Miller 2002).

\subsection{Data analysis}

All 90 s recordings were sorted by day and then concatenated and converted into wav files using custom Matlab v.2014b (The MathWorks) scripts. Daily files were inspected visually and aurally for cetacean sounds by visualizing the entire file using TRITON (Wiggins \& Hildebrand 2007). The daily occurrence of all species detected was summarized. Those files containing killer whale sounds were further reviewed, and discrete calls were compared to a catalog of pod- and population-specific pulsed calls to determine the killer whale ecotype, population, clan (in the case of NRKW), and pod (if possible, in the case of SRKW) (Ford 1987). Killer whale detections of insufficient quality to determine ecotype and population were not included in this analysis.

For all resident killer whale detections, the types of sounds (clicks, calls, buzzes) in each 90 s recording were identified, and these recordings were organized into acoustic encounters using methods described by Riera et al. (2013). Encounters were defined as periods in which sounds produced by the same group of whales could be detected over multiple sequential recordings separated by less than $3 \mathrm{~h}$, and the duration of these encounters was also determined in decimal hours. Monthly median encounter length was calculated for each population. We compared the effect of resident killer whale population on encounter length using a Mann Whitney $U$-test.

Rates of monthly occurrence were calculated by dividing the number of days in a given month by the total number of days of effort in that month. To investigate spatial differences in monthly occurrence, 
recorder sites were first grouped into north and south groups. These groups were determined by proximity to the Straits of Juan de Fuca to the north and the Columbia River to the south. The northern sites were Juan de Fuca, Cape Flattery mid-shelf, Cape Flattery offshore, Cape Flattery deep, Sandpoint, and La Push. The southern sites were Quinault deep, Quinault mid-shelf, Quinault inshore, Westport, Westport mid-shelf, Westport deep, Willapa, Columbia River, and Columbia River south. Secondly, sites were grouped by distance from shore: inshore, mid-shelf, and offshore. The inshore sites were Juan de Fuca, Sandpoint, La Push, Quinault inshore, Westport, Willapa, and Columbia River. The mid-shelf sites were Cape Flattery mid-shelf, Quinault mid-shelf, Westport mid-shelf, and Columbia River south. The offshore sites were Cape Flattery offshore, Cape Flattery deep, Quinault deep, and Westport deep.

\section{RESULTS}

Between 2014 and 2017, the number of days monitored by location ranged from $69 \mathrm{~d}$ at Quinault mid-shelf to $1149 \mathrm{~d}$ at Columbia River North (Fig. 2). Resident killer whales were detected acoustically 429 times, with detections at all sites except for Quinault Deep. Total duration was $490.9 \mathrm{~h}$ for the 263 SRKW encounters, and $441.3 \mathrm{~h}$ for the 166 NRKW encounters. SRKW were detected at 10 of the 15 sites, while NRKW were detected at 11 of the 15 sites. SRKW were detected in every month of the year but August (Fig. 3B), and $66.2 \%$ of these encounters were between February and May $(n=174)$. NRKW were detected in every month of the year with 2 peaks in occurrence (Fig. 3B): one peak was between February and April with $42.8 \%$ of all NRKW encounters $(\mathrm{n}=71)$ and the second between August and October with $37.3 \%$ of all NRKW encounters $(\mathrm{n}=62)$. All 3 SRKW pods were detected at the northern sites, while only 2 ( $\mathrm{K}$ and $\mathrm{L}$ pods) were detected at the southern sites. The majority of NRKW encounters were of G clan, but all 3 clans were detected. The median SRKW encounter length was $1.33 \mathrm{~h}$ and ranged from

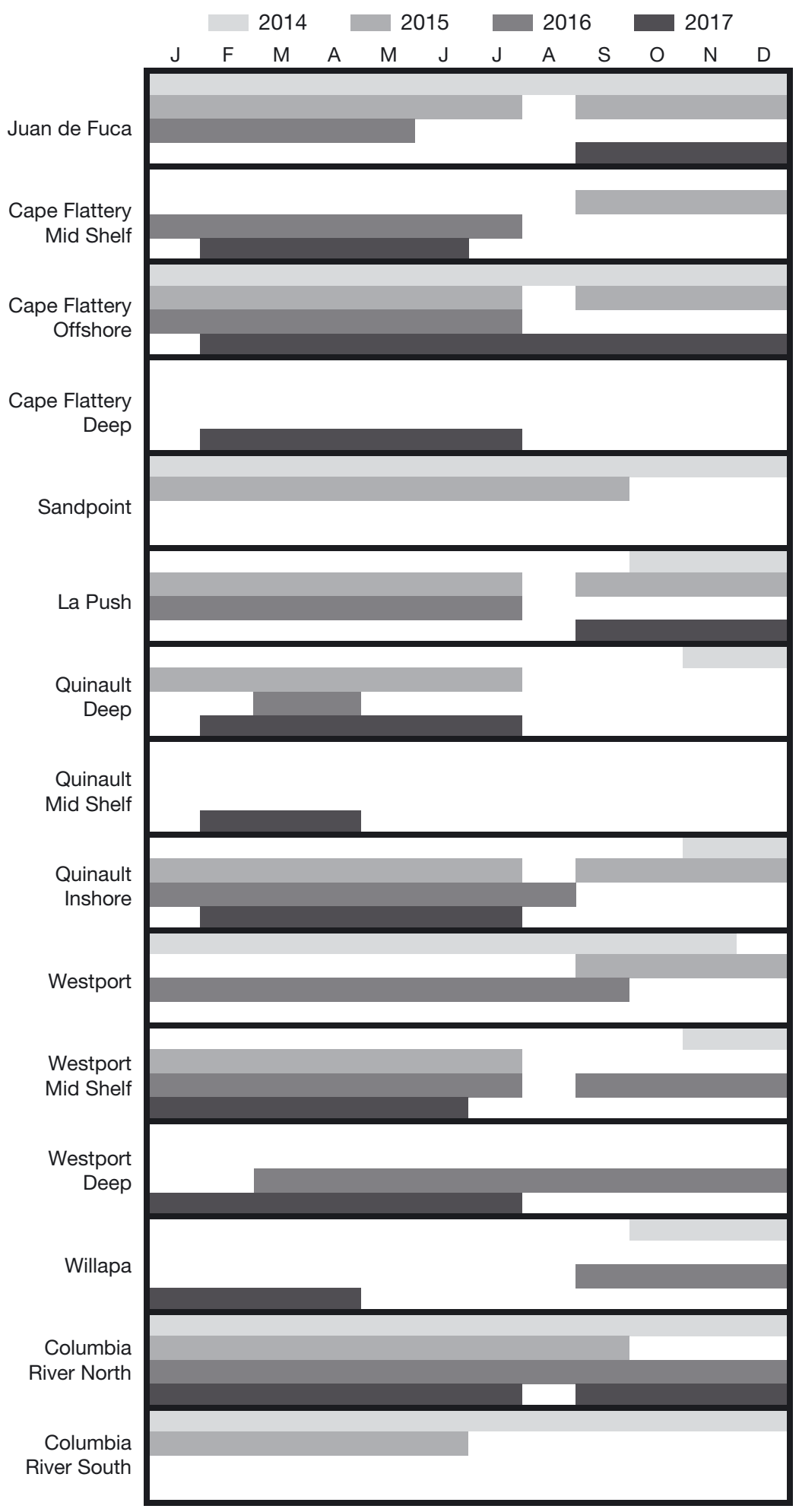

Fig. 2. Monthly and yearly effort for each acoustic recorder site 

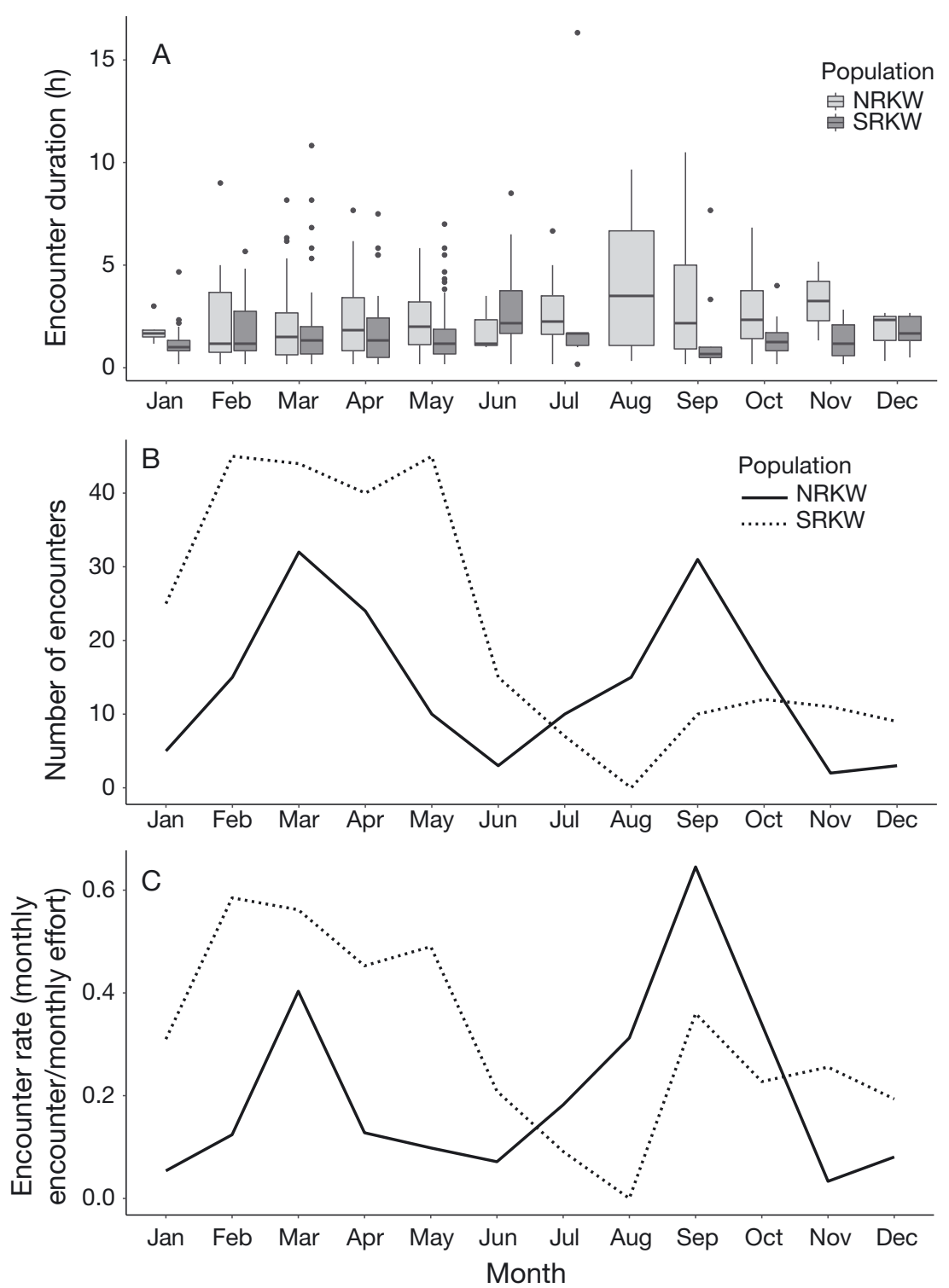

Fig. 3. (A) Monthly encounter length for Northern Resident (NRKW) and Southern Resident killer whales (SRKW) in hours, (B) monthly count of encounters at all sites and (C) monthly encounter rate. In (A), horizontal lines within the boxes: median; box boundaries: $25^{\text {th }}$ (lower boundary) and $75^{\text {th }}$ (upper boundary) percentiles; whiskers: minimum and maximum values within 1.5 times the interquartile range; dots: values outside that range

$2 \mathrm{~h}$ for all months but June (median $=$ $2.2 \mathrm{~h}$ ) and September (median $=0.7 \mathrm{~h}$ ). For NRKW, monthly median encounter duration ranged from $1.2-3.5 \mathrm{~h}$ (Fig. 3A) and was greater than $2 \mathrm{~h}$ in May and July-December. Median encounter duration was longer for NRKW than SRKW in all months but February and June.

The majority of resident killer whale (NRKW and SRKW) encounters (63\%) were at the northern sites. Less than half of the SRKW encounters $(45 \%)$ were at the northern sites and 55\% were at the southern sites (Fig. 4B). In contrast, $93 \%$ of all NRKW encounters were at the northern sites (Fig. 4B). The occurrence of encounters peaked in the fall at northern sites and in the spring at southern sites (Fig. 4A).

The inshore sites accounted for a little over half of all resident killer whale (NRKW and SRKW) encounters $(53 \%)$. The majority $(83 \%)$ of SRKW encounters were at these inshore sites, while only $5 \%$ of NRKW were at these sites (Fig. 5B). The mid-shelf sites accounted for $16 \%$ of resident encounters: $14 \%$ of SRKW and $18 \%$ of NRKW encounters (Fig. 5B). The offshore sites accounted for $31 \%$ of all resident encounters. Only $3 \%$ of SRKW encounters were at these sites, but $76 \%$ of NRKW encounters were at these offshore sites (Fig. 5B). The few SRKW encounters at the offshore sites were in the spring months. The spring and fall peaks in NRKW encounters occurred at the mid-shelf and offshore sites.

\section{DISCUSSION}

0.17-16.33 $\mathrm{h}$. The median NRKW encounter length was $1.92 \mathrm{~h}$ and ranged from $0.17-10.33 \mathrm{~h}$. The proportion of encounters longer than $2 \mathrm{~h}$ was lower for NRKW (33.5\%) than for SRKW (50\%) encounters. Encounter lengths for NRKW (median $=1.92$ ) were longer than those for SRKW (median = 1.33). A Mann-Whitney test indicated that this difference was statistically significant $(U=26027.5, \mathrm{p}<0.001)$.

The monthly median encounter duration for SRKW ranged from $0.7-2.2 \mathrm{~h}$ (Fig. 3). It was between 1 and
Passive acoustic monitoring was used to describe the temporal and spatial occurrence of resident killer whales off the Washington coast. SRKW and NRKW were both detected throughout the year with detection peaks in the spring and fall, seasons in which there are very few vessel surveys due to challenging weather conditions, further illustrating the importance of PAM for year-round monitoring of these populations. 

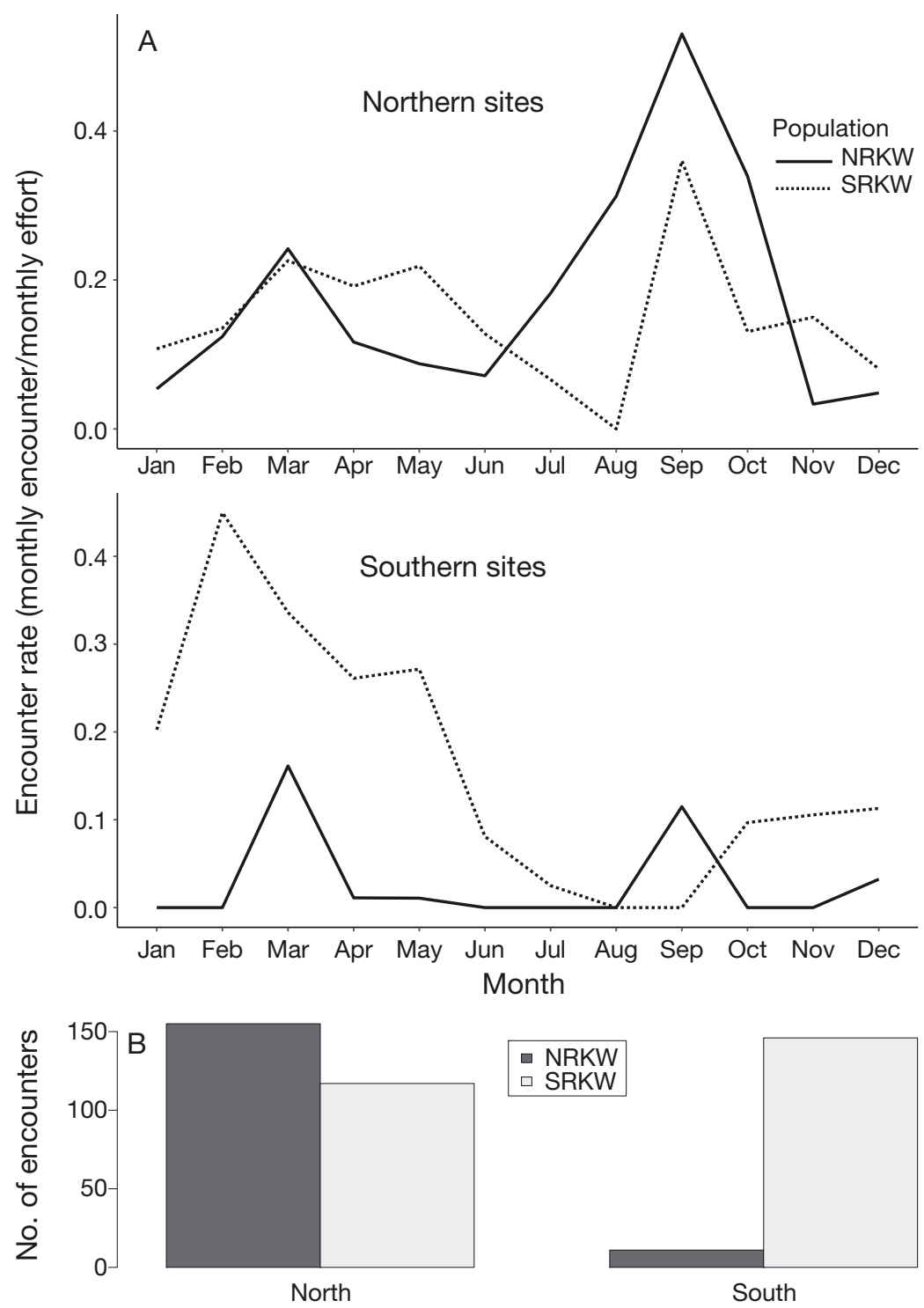

Fig. 4. (A) Monthly encounter rate at northern and southern sites and (B) total number of encounters at northern and southern sites

Interpretation of PAM results is enhanced by an understanding of factors that may impact the detectability of resident killer whales, such as detection range and vocal behavior. The detection range can be influenced by both natural and anthropogenic sounds that may mask killer whale vocalizations. Our ability to detect killer whales may be impacted by seasonal changes in wind speed and precipitation (Lemon et al. 1984, Robinson et al. 2019). Riera et al. 2019 modeled the detection range for resident killer whales at Swiftsure Bank, to the north of the study area, for 4 months of the year: January, June, July, and September. The monthly mean detection distance varied seasonally from $5 \mathrm{~km}$ in January to
$6.5 \mathrm{~km}$ in September, with intermediate values in June and July. These results indicate that the detection range did not vary greatly throughout the year, but decreased slightly in the winter. Sound associated with large commercial vessels, fishing vessels, and small personal craft can also reduce the detection range, and the intensity of these activities varies across the continental shelf. In this study, the detection rates of resident killer whales did not vary greatly between inshore sites $(4.8 \%$ of days) and offshore sites (5.9\% of days), but we acknowledge the uncertainty that seasonal and temporal changes in detection range may play in interpreting our results.

Resident killer whales have been shown to vocalize more while foraging and socializing than when traveling and resting (Ford 1989, Holt et al. 2013). However, SRKW have been documented to vocalize less than $44 \%$ of the time in these coastal waters in the winter (Hanson et al. 2018). This means that the results of this study represent the minimum occurrence of these 2 resident killer whale populations. Encounter duration can provide further information on habitat use; longer durations indicate that the whales are using the area for a range of behaviors, including foraging and socializing, rather than just transiting though it (Riera et al. 2019).

Previous studies using PAM and visual surveys have described limited use of the Washington coast by NRKW (Ford et al. 2017, Rice et al. 2017), although in the present study they accounted for over one-third of all resident killer whale encounters. The majority of these encounters were at northern sites and were longer than those of SRKW, indicating more extensive use of the Washington coast than previously reported.

With the overlapping ranges and similar prey preferences of these 2 resident killer whale populations, it is important to understand the role that competition may play in limiting the recovery of SRKW (Chasco et al. 2017). Competition for prey resources may result in spatial or temporal habitat segregation (Johnson \& Crowley 1980, Martin \& de Silva 2004). In 

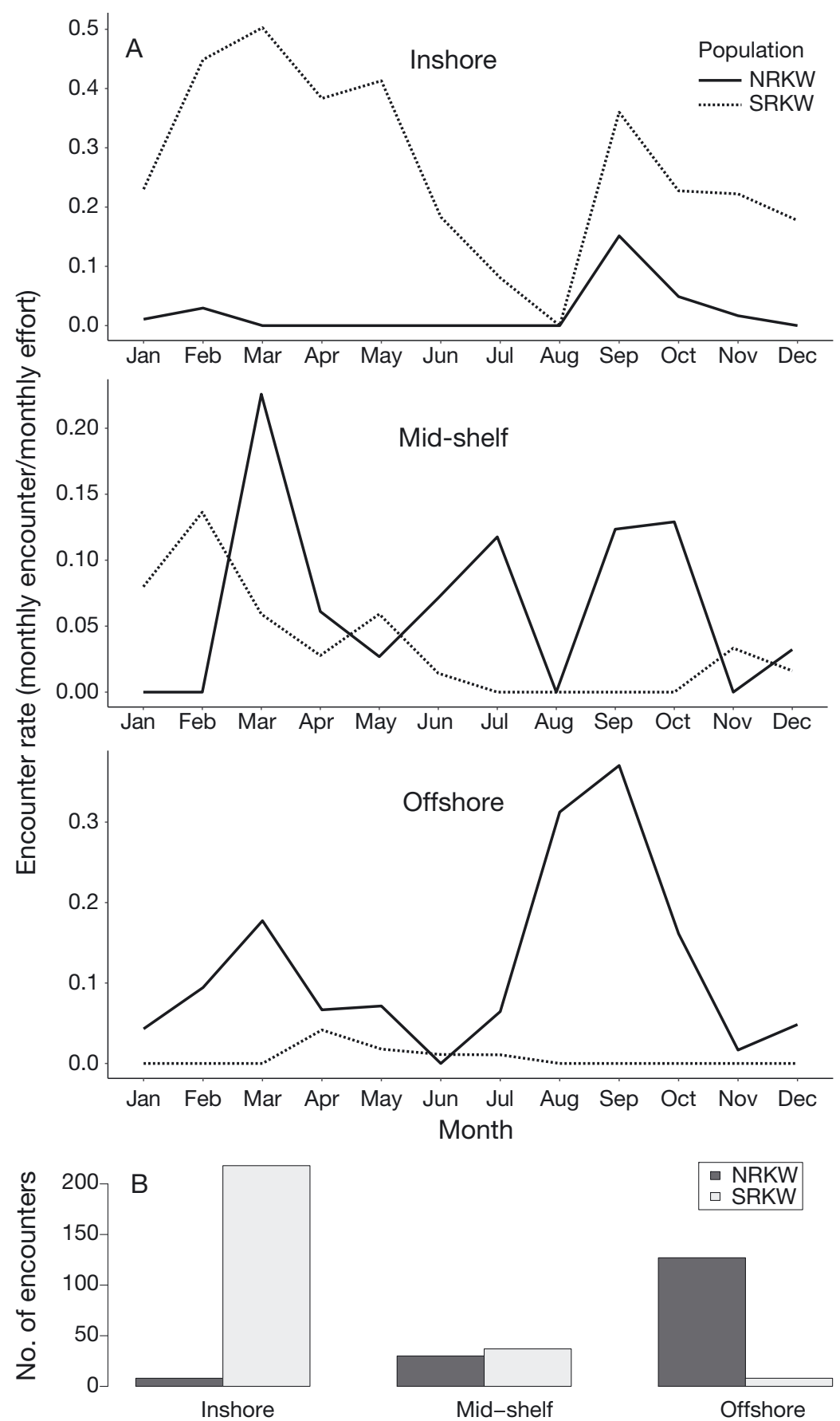

Fig. 5. (A) Monthly encounter rate at inshore, mid-shelf and offshore sites and (B) total number of encounters at inshore, mid-shelf, and offshore sites

fall peaks in occurrence, but the spring peak was driven by an increase in SRKW encounters at the southern sites, while the fall peak was driven by an increase in NRKW encounters at northern sites. The 2 populations were also segregated across the shelf, with SRKW occurring primarily at inshore sites and NRKW at offshore sites. These findings were made possible by monitoring an expanded area using a large network of recorders across diverse sites as opposed to one or 2 sites as in previous studies.

The spring and fall peaks in occurrence for both populations suggest that both may be targeting similar prey. Previous studies in the inland waters have shown that both NRKW and SRKW exhibit a strong preference for Chinook salmon (Ford et al. 1998, Ford \& Ellis 2006, Hanson et al. 2010, Ford et al. 2016), but there is limited diet data available for the coastal waters. The spring peak in occurrence aligns with previous sightings of SRKW near the Columbia River (Zamon et al. 2007, Hanson et al. 2018) and the return of spring Chinook salmon to the Columbia River, the largest run in the region at this time of year (Hanson et al. 2013). Diet data collected along the outer coast have been limited to spring months and indicate that Chinook salmon are an important component of SRKW throughout the year (Hanson et al. 2021). While fall coastal diet data are lacking, Chinook salmon typically return to the Fraser River from JulyOctober (Groot \& Margolis 1991). However, care must be taken when correlating killer whale and salmon movements. For example, observations of NRKW predation on sablefish near the shelf break mainly in the month of September (Ford et al. 2017) suggest that killer whale movements may not

addition to temporal habitat partitioning reported in previous studies (Yurk et al. 2010, Rice et al. 2017, Riera et al. 2019), the data presented here indicate that spatial separation of the 2 resident killer whale populations is also occurring along the Washington coast. Both NRKW and SRKW exhibited spring and be entirely dependent upon the distribution of Chinook salmon.

In conclusion, we observed both spatial and temporal habitat partitioning by NRKW and SRKW along the coast of Washington State. Our data show that populations with similar prey preferences can parti- 
tion to reduce competitive interactions. Recognizing these differences in habitat use is critical, since the whales' exposure to anthropogenic activities may differ as a result. For example, sounds associated with military activities were most frequently detected at the offshore sites, while sounds associated with fishing were most frequently detected at the mid-shelf sites (Emmons et al. 2019b). This study provides further information about the habitat use ofthese resident killer whale populations with implications for their management and conservation in proposed critical habitat.

Acknowledgements. We thank the US Navy Pacific Fleet for providing funding support for this work. We are also grateful to the NOAA Hollings Undergraduate Scholarship program, and in particular Amelia Johnson and Draven Hawk, for assistance with classifying sound types. We also thank $\mathrm{M}$. Craig, S. Smith, T. Nesseth, and the crews of the R/V 'Centennial' and F/V 'Cape Windy' for deployment and recovery of the acoustic recorder moorings. D. Holzer provided Fig. 1. Research was conducted in the Olympic Coast National Marine Sanctuary under permits OCNMS-2012-008, OCNMS2014-006, OCNMS-2016-002, and OCNMS-2017-009.

\section{LITERATURE CITED}

Ayres KL, Booth RK, Hempelmann JA, Koski KL and others (2012) Distinguishing the impacts of inadequate prey and vessel traffic on an endangered killer whale (Orcinus orca) population. PLOS ONE 7:e36842

Bearzi M (2005) Dolphin sympatric ecology. Mar Biol Res 1: 165-175

Brent LJN, Franks DW, Foster EA, Balcomb KC, Cant MA, Croft DP (2015) Ecological knowledge, leadership, and the evolution of menopause in killer whales. Curr Biol 25:746-750

* Chasco BE, Kaplan IC, Thomas AC, Acevedo-Gutiérrez A and others (2017) Competing tradeoffs between increasing marine mammal predation and fisheries harvest of Chinook salmon. Sci Rep 7:15439

* Dahlheim ME, Schulman-Janiger A, Black N, Ternullo R, Ellifrit D, Balcomb KC (2008) Eastern temperate North Pacific offshore killer whale (Orcinus orca): occurrence, movements and insights into feeding ecology. Mar Mamm Sci 24:719-729

Eguiguren A, Pirotta E, Cantor M, Rendell L, Whitehead H (2019) Habitat use of culturally distinct Galapagos sperm whale Physeter macrocephalus clans. Mar Ecol Prog Ser 609:257-270

Emmons CK, Hard JJ, Dahlheim ME, Waite JM (2019a) Quantifying variation in killer whale (Orcinus orca) morphology using elliptical Fourier analysis. Mar Mamm Sci 35:5-21

Emmons CK, Hanson M, Lammers M (2019b) Monitoring the occurrence of southern resident killer whales, other marine mammals, and anthropogenic sound in the Pacific Northwest. Prepared by: National Oceanic and Atmospheric Administration, Northwest Fisheries Science Center under MIPR N00070-17-MP-4C419
Fisheries and Oceans Canada (2018) Recovery strategy for the northern and southern resident killer whales (Orcinus orca) in Canada. Species Risk Act Recovery Strategy Series. Fisheries and Oceans Canada, Ottawa

Ford JKB (1987) A catalogue of underwater calls produced by killer whales (Orcinus orca) in British Columbia. Can Data Rep Fish Aquat Sci 633:1-165

Ford JKB (1989) Acoustic behavior of resident killer whales (Orcinus orca) off Vancouver Island, British Columbia. Can J Zool 67:727-745

Ford JKB, Ellis GM (2006) Selective foraging by fish-eating killer whales Orcinus orca in British Columbia. Mar Ecol Prog Ser 316:185-199

Ford JKB, Ellis GM, Barrett-Lennard LG, Morton AB, Palm RS, Balcomb KC III (1998) Dietary specialization in two sympatric populations of killer whales (Orcinus orca) in coastal British Columbia and adjacent waters. Can J Zool 76:1456-1471

Ford JKB, Ellis GM, Balcomb KC (2000) Killer whales: the natural history and genealogy of Orcinus orca in British Columbia and Washington, $2^{\text {nd }}$ edn. UBC Press, Vancouver

Ford JKB, Pilkington JF, Reira A, Otsuki M and others (2017) Habitats of special importance to resident killer whales (Orcinus orca) off the west coast of Canada. DFO Can Sci Advis Sec Res Doc 2017/035

* Ford MJ, Hempelmann J, Hanson MB, Ayers KL and others (2016) Estimation of a killer whale diet (Orcinus orca) population's diet using sequencing analysis of DNA from feces. PLOS ONE 11:e0144956

*Genov T, Centrih T, Kotnjek P, Hace A (2019) Behavioral and temporal partitioning of dolphin social groups in the northern Adriatic Sea. Mar Biol 166:11

Groot C, Margolis L (eds) (1991) Pacific salmon life histories. UBC Press, Vancouver

*Hanson MB, Baird RW, Ford JKB, Hempelmann-Halos J and others (2010) Species and stock identification of prey consumed by endangered southern resident killer whales in their summer range. Endang Species Res 11:69-82

*Hanson MB, Emmons CK, Ward EJ, Nystuen JA, Lammers MO (2013) Assessing the coastal occurrence of endangered killer whales using autonomous passive acoustic recorders. J Acoust Soc Am 134:3486-3495

Hanson MB, Ward E, Emmons C, Holt M (2018) Modeling the occurrence of endangered killer whales near a US Navy training range in Washington State using satellitetag locations to improve acoustic detection data. Prepared by: NOAA, Northwest Fisheries Science Center, Seattle, WA, under MIPR N00070-17-MP-4C419

* Hanson MB, Emmons CK, Ford MJ, Everett M and others (2021) Endangered predators and endangered prey: seasonal diet of Southern Resident killer whales. PLOS ONE 16:e0247031

Hickey BM, Banas NS (2003) Oceanography of the US Pacific Northwest coastal ocean and estuaries with application to coastal ecology. Estuaries 26:1010-1031

*Holt MM, Noren DP, Emmons CK (2013) An investigation of sound use and behavior in a killer whale (Orcinus orca) population to inform passive acoustic monitoring studies. Mar Mamm Sci 29:E193-E202

Johnson DM, Crowley PH (1980) Habitat and seasonal segregation among coexisting odonate larvae. Odonatologica 9:297-308

* Lammers MO, Brainard RE, Au WWL, Mooney TA, Wong $\mathrm{KB}$ (2008) An ecological acoustic recorder (EAR) for 
long-term monitoring of biological and anthropogenic sounds on coral reefs and other marine habitats. J Acoust Soc Am 123:1720-1728

Lemon DD, Farmer DM, Watts DR (1984) Acoustic measurements of wind speed and precipitation over a continental shelf. J Geophys Res 89:3462-3472

Martin AR, da Silva VMF (2004) River dolphins and flooded forest: seasonal habitat use and sexual segregation of botos (Inia geoffrensis) in an extreme cetacean environment. J Zool 263:295-305

Miller PJ (2002) Mixed-directionality of killer whale stereotyped calls: A direction of movement cue? Behav Ecol Sociobiol 52:262-270

NMFS (National Marine Fisheries Service) (2006) Designation of critical habitat for southern resident killer whale. Fed Reg 71:69054-69070

NMFS (2019) Proposed rulemaking to revise critical habitat for the southern resident killer whale distinct population segment. Fed Reg 84:49214-49235

Olson JK, Wood J, Osborne RW, Barrett-Lennard L, Larson S (2018) Sightings of southern resident killer whales in the Salish Sea 1976-2014: the importance of a long-term opportunistic dataset. Endang Species Res 37:105-118

* Oviedo L, Fernández M, Herra-Miranda D, PachecoPolanco JD, Hernández-Camacho C, Aurioles-Gamboa D (2018) Habitat partitioning mediates the coexistence of sympatric dolphins in a tropical fjord-like embayment. J Mammal 99:554-564

Ratcliffe N, Crofts S, Brown R, Baylis AMM and others (2014) Love thy neighbour or opposites attract? Patterns of spatial segregation and association among crested penguin populations during the winter. J Biogeogr 41: 1183-1192

Rice A, Deecke VB, Ford JKB, Pilkington JF, Oleson EM, Hildebrand JA, Širovic A (2017) Spatial and temporal occurrence of killer whale ecotypes off the outer coast of Washington State, USA. Mar Ecol Prog Ser 572:255-268

Riera A, Ford JK, Chapman NR (2013) Effects of different analysis techniques and recording duty cycles on passive acoustic monitoring of killer whales. J Acoust Soc Am 134:2393-2404

Riera A, Pilkington JF, Ford JKB, Stredulinsky EH, Chapman NR (2019) Passive acoustic monitoring of Vancouver Island reveals extensive use by at-risk Resident killer whale (Orcinus orca) populations. Endang Species Res 39:221-234

Editorial responsibility: Jeremy Kiszka,

North Miami, Florida, USA

Reviewed by: 2 anonymous referees
Robinson C, Barclay DR, Vagle S (2019) Modelling the coastal, ambient, marine noise field in space, time and frequency. J Acoust Soc Am 146:3027

Schevill WE, Watkins WA (1966) Sound structure and directionality in Orcinus (killer whale). Zoologica (NY) 51:71-76

Shelton AO, Satterthwaite WH, Ward EJ, Feist BE, Burke B (2019) Using hierarchical models to estimate stock-specific and seasonal variation in ocean distribution, survivorship, and aggregate abundance of fall run Chinook salmon. Can J Fish Aquat Sci 76:95-108

Teixeira CR, Botta S, Daura-Jorge FG, Pereira LB, Newsome SD, Simoes-Lopez PC (2021) Niche overlap and diet composition of three sympatric coastal dolphin species in the southwest Atlantic Ocean. Mar Mamm Sci 37: 111-126

Towers JR, Pilkington JF, Gisborne B, Wright BM, Ellis GM, Ford JKB, Doniol-Valcroze T (2020) Photo-identification catalogue and status of the northern resident killer whale population in 2019. Can Tech Rep Fish Aquat Sci 3371

Ward EJ, Ford MJ, Kope RG, Ford JKB and others (2013) Estimating the impacts of Chinook salmon abundance and prey removal by ocean fishing on southern resident killer whale population dynamics. NOAA Tech Memo NMFS-NWFSC-123

Weitkamp LA (2010) Marine distributions of Chinook salmon from the west coast of North America determined by coded wire tag recoveries. Trans Am Fish Soc 139: $147-170$

Wiggins SM, Hildebrand JA (2007) High-frequency acoustic recording package (HARP) for broad-band, long-term marine mammal monitoring. In: International Symposium on Underwater Technology 2007 and International Workshop on Scientific Use of Submarine Cables \& Related Technologies 2007. Institute of Electrical and Electronics Engineers, Tokyo, p 551-557

* Yurk H, Filatova O, Matkin CO, Barrett-Lennard LG, Brittain $M$ (2010) Sequential habitat use by two resident killer whale (Orcinus orca) clans in Resurrection Bay, Alaska, as determined by remote acoustic monitoring. Aquat Mamm 36:67-78

Zamon JE, Guy TJ, Balcomb K, Ellifrit D (2007) Winter observations of southern resident killer whales (Orcinus orca) near the Columbia River plume during the 2005 spring Chinook salmon (Oncorhynchus tshawytscha) spawning migration. Northwest Nat 88:193-198

Submitted: June 25, 2020

Accepted: November 23, 2020

Proofs received from author(s): March 9, 2021 